$/ 5 / 7-86$ y6

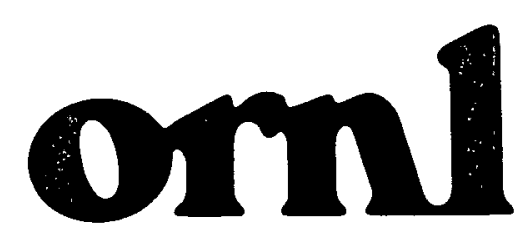

1

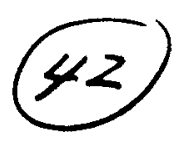

ORNL/TM-9988

\title{
Use of High-Pressure Ion Exchange for the Production of Gadolinium-153, Status Report
}

J. C. Posey

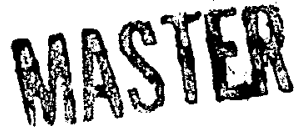

DISTRIBUTION OF THHS DOCUMENT IS UHUMTTE 


\section{DISCLAIMER}

This report was prepared as an account of work sponsored by an agency of the United States Government. Neither the United States Government nor any agency Thereof, nor any of their employees, makes any warranty, express or implied, or assumes any legal liability or responsibility for the accuracy, completeness, or usefulness of any information, apparatus, product, or process disclosed, or represents that its use would not infringe privately owned rights. Reference herein to any specific commercial product, process, or service by trade name, trademark, manufacturer, or otherwise does not necessarily constitute or imply its endorsement, recommendation, or favoring by the United States Government or any agency thereof. The views and opinions of authors expressed herein do not necessarily state or reflect those of the United States Government or any agency thereof. 


\section{DISCLAIMER}

Portions of this document may be illegible in electronic image products. Images are produced from the best available original document. 
ORNL/TM--9988

DE86 010062

ORNL/TM-9988

Distribution Category UC-70

Operations Division

OAK RIDGE NATIONAL LABORATORY

USE OF HIGH-PRESSURE ION EXCHANGE POR THE PRODUCTION OF GADOLINIUM-153, STATUS REPORT

J. C. Posey

Radioisotope Technology Isotope Production Department

Date Published - April 1986

NOTICE This document contains information of a preliminary nature. It is subject to revision or correction and therefore does not represent a final report.

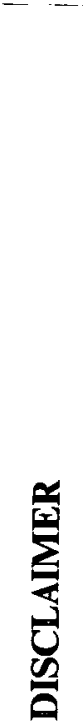

\footnotetext{
Prepared by the

Oak Ridge National Laboratory

Oak Ridge, Tennessee 37831 operated by Martin Marietta Energy Systens, Inc. for the

U.S. DEPARTMENT OF ENERGY

under Contract No. DE-AC05-840R21400
}

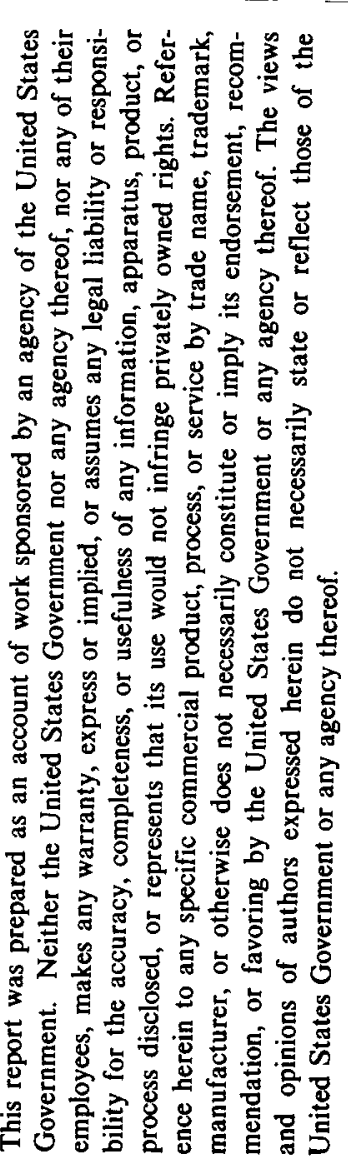


Operations Division

OAK RIDGE NATIONAL LABORATORY

USE OF HIGH-PRESSURE ION EXCHANGE POR THE PRODUCTION OF
GADOLINIUM-153, STATUS REPORT

\author{
J . C. Posey \\ Radioisotope Technology \\ Isotope Production Department
}

\begin{abstract}
A large high-pressure ion-exchange column, which had been designed for the separation of gadolinium from europium, was tested in the laboratory. Good separations were obtained. Subsequently, columns of the same design were installed in a hot cell and have been used successfully for the separation of gadolinium-153 from irradiated natural europium. The gadolinium-153 production achieved using these columns is substantially greater than that achieved using the previous process. Rapid damage of the resin is a problem and frequent resin changes are required.
\end{abstract}

A method of increasing the rate and efficiency of production of gadolinium-153 was needed. The demand for this isotope exceeded our production capacity, and further increases in demand were expected.

Gadolinium-153 is produced by the neutron irradiation of natural europium. A large amount of radioactive europium also is produced and must be separated from the gadolinium: A large part of the expense and the greater part of the gadolinium losses have occurred during this separation.

Previously, the europium had been precipitated as. EuSO 4 after reduction by amalgamated zinc. This removed most but not all of the europium. A second purification was carried out using a small high-pressure ionexchange column. The conversion of the gadolinium sulfate from the precipitation process to a suitable feed solution for the ion-exchange process required several steps, including oxalate precipitation, calcining, and the removal of zinc by an anion-exchange process.

other separation processes had been investigated. They were:

1. an electrolytic process in which the europium was removed from solution using a mercury cathode, 
2. a solvent extraction process in which the gadolinium was extracted away from the europium by di-(2 ethylhexyl) phosphoric acid after the europium has been reduced to the divalent form, and

3. a vaporization process in which europium metal was volatilized away from the gadolinium metal.

All of these processes achieved a substantial degree of separation, but in all cases, a second purification step was required to produce material of the required radiochemical purity, i.e., $>99.99 \%$.

High-pressure ion exchange* was chosen as the best prospect. Our experience with the small high-pressure column and literature on the method indicated a high probability of success. The separation of gadolinium from europium had been demonstrated on a tracer level by Brown and Callahan.' Campbell ${ }^{2}$ had demonstrated the separation of all of the lanthanides from each other. Others such as Benker, et al. ${ }^{3}$, and Campbell ${ }^{4}$ had separated trivalent actinides from each other.

\section{Chemistry of Process}

The ion-exchange reaction in the column is given by chemical Eq. 1 .

$$
\mathrm{GdR}_{3}+3 \mathrm{NH}_{4}^{+}+\mathrm{AHIB}^{-} \rightleftarrows \mathrm{Gd}(\mathrm{AHIB})^{2+}+3 \mathrm{NH}_{4} \mathrm{R}
$$

where $A A^{-} B^{-}=$the alpha hydroxyisobutyrate ion,

$$
\mathrm{R}=\text { the cation exchange radical in resin }\left(-\mathrm{SO}_{2}^{-}\right) \text {. }
$$

Some Gd(AHIB $)_{2}{ }^{+}$may also be formed. The reaction of europium is the same, except the equilibrium constant is about $30 \%$ higher for gadolinium.

Simple equilibrium considerations indicate that the ratio of europium (or gadolinium) concentration in solution to that in the resin is proportional to the $\mathrm{AHIB}^{-}$concentration and to the cube of the $\mathrm{NH}_{4}^{+}$concentration. In most real cases; however, considerable deviation can be expected because of changes in resin loading, changes in activity coefficients, formation of higher complexes, etc.

*High-pressure ion exchange is also called rapid ion exchange. It uses ion-exchange beads of very small size. The small beads equilibrate quickly with the aqueous solution because of their small internal distances and large ratio of surface area to volume. Much higher elutant flow rates can be used than in the case of conventional ion exchange. Unfortunately, the small particle size also causes the resistance to flow to be high, and high pressure is required to cause the elutant to flow at the desired rate through a column, hence, the name high-pressure ion exchange. The high pressure has a second advantage when used with radioactive materials. Radiochemically produced gases stay in solution and do not form bubbles. Bubbles often disrupt the column and cause nonuniform flow when ionexchange separations are carried out at near-ambient pressure with radioactive solutions. 
The eluting solution is made by partially neutralizing the acid form of AHIB with ammonium hydroxide. Consequently, the $\mathrm{NH}_{4}{ }^{+}$ion and $\mathrm{AHIB}^{-}$ion concentrations are equal and increase with the degree of neutralization.

Table 1 gives values calculated for 0.15 M AHIB solution using a $\mathrm{pK}$ value of 3.98 taken from the data of Smith and Hoffman.

Table 1. Active ion concentrations in partially neutralized AHIB

\begin{tabular}{lcc}
\hline $\mathrm{pH}$ & $\begin{array}{c}\left(\mathrm{AHIB}^{-}\right) \text {or } \\
\text { concentration } \\
(\text { molar })\end{array}$ & $\begin{array}{c}\text { Ratio to concentration } \\
\text { at } \mathrm{pH}=4.5\end{array}$ \\
\hline 4.2 & 0.094 & 0.81 \\
4.3 & 0.101 & 0.88 \\
4.4 & 0.109 & 0.94 \\
4.5 & 0.115 & 1.00 \\
4.6 & 0.121 & 1.05 \\
4.7 & 0.126 & 1.09 \\
5.0 & 0.137 & 1.19 \\
\hline
\end{tabular}

Because both the $\mathrm{NH}_{4}^{+}$and $\mathrm{AHIB}^{-}$concentrations increase with $\mathrm{pH}$, the equilibrium shown by Eq. 1 is strongly affected by the $\mathrm{pH}$.

The ion-exchange columns used for gadolinium-153 production are essentially the same in design as the column described by Brown and Callahan." The ionexchange column was increased in size to 0.625 in. I.D., 25 in. length, and contained $125 \mathrm{~cm}^{3}$ of resin. The sizes of other parts were unchanged. The system was designed to allow easy replacement of the resin. The necessity of frequent replacement was anticipated because of the intense ionizing radiation. The system and its operation are shown in Figs. 1 through 6 , which are taken from Ref.' 1 .

Aminex Q-150S ion-exchange resin is used. This is a Dowex 50-type resin of $28 \pm 7 \mu$ particle diameter. It is received in the sodium form but is converted to the hydrogen form before loading into the column. Because of the small particle size, the resin has a slow settling rate, about $0.6 \mathrm{~cm} / \mathrm{min}$, and can be easily transported from vessel to vessel in the system by a flow of water.

The method of loading the resin into the column is shown in Figs. 1 and 2 . The resin is first loaded into a dummy column outside the hot cell. This column is identical, except for the water jacket; to the one in the hot cell. This step measures the amount of resin required. This dummy column is connected in a line between the high-pressure pump and the resin reservoir (top left in Figs. 1 through 6). A stream of water is pumped through the dummy column and the reservoir. This carries the resin into the reservoir where it is retained by a filter in the top exit. 
The resin is transferred to the column using the flows shown in Figure 2 . It is retained in the column by a stainless steel filter at the bottom of the column.

The gadolinium/europium charge is introduced in a $25-\mathrm{mL}$ volume of $0.05 \mathrm{M}$ nitric acid. The liquid flows are shown in Figure 2. The charge is introduced first into the glass vessel at the extreme right. Mild air pressure applied through the top of the vessel causes the solution to flow into the high-pressure loading reservoir. This is followed by two rinses using 0.05 M nitric acid to ensure complete transfer. The second glass vessel catches any solution accidentally bubbled out of the loading reservoir.

The europium/gadolinium charge is moved into the column as shown in Figure 2. A $10 \%$ solution of lithium nitrate is pumped into the bottom of the high-pressure feed reservoir using the high-pressure pump. The gadolinium/europium solution floats on this dense solution and is forced into the high-pressure ion-exchange column. The lithium nitrate is flushed from the column with $0.25 \mathrm{M}$ ammonium nitrate.

Elution is carried out using 0.15 M AHIB solution that has been neutralized to a pH of 4.46 with concentrated ammonium hydroxide. The flows are shown in Figure 3 . The flow rate is $25 \mathrm{~mL} / \mathrm{min}$. The column is heated by a water jacket using water from a bath at $86^{\circ} \mathrm{C}$. The radioactive content of the effluent stream is monitored by means of an ionization chamber.

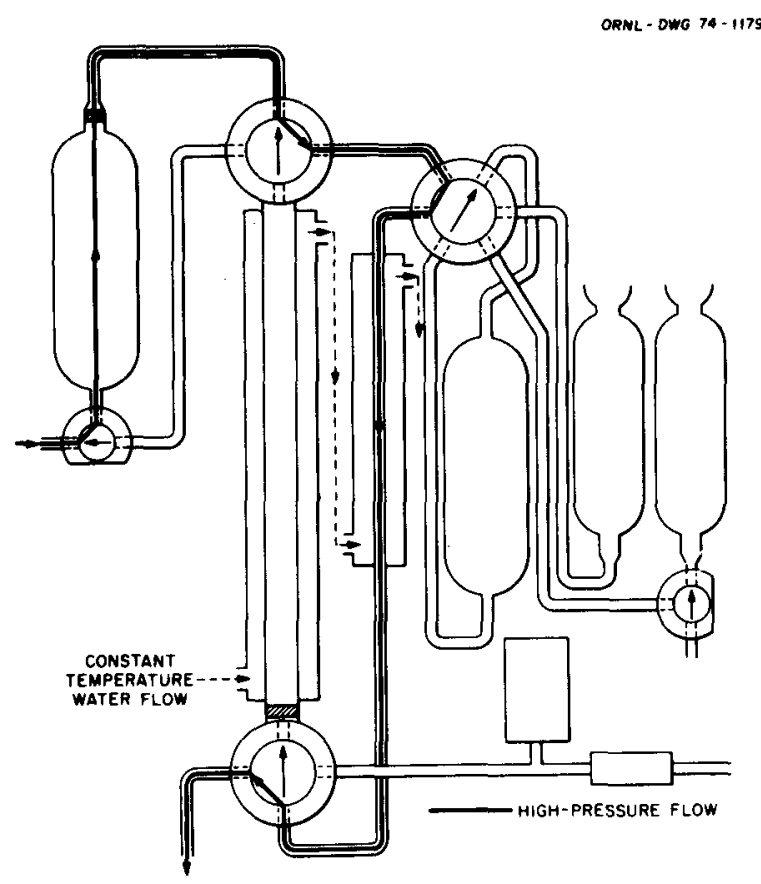

Fig. 1. Initial Apparatus Resin Loading Sequence.

PEPDODUCED FPOM DET HAILABLE OOPY

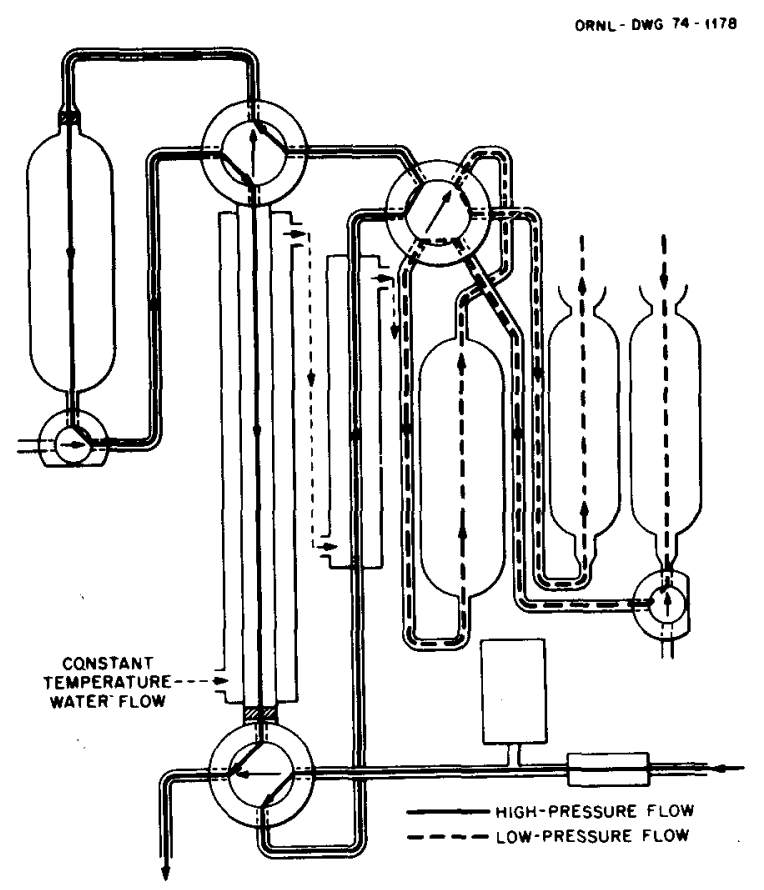

Fig. 2. High-pressure Transfer of Resin into Column and Low-pressure Transfer of Column Charge Solution into High-Pressure Loading Reservoir. 

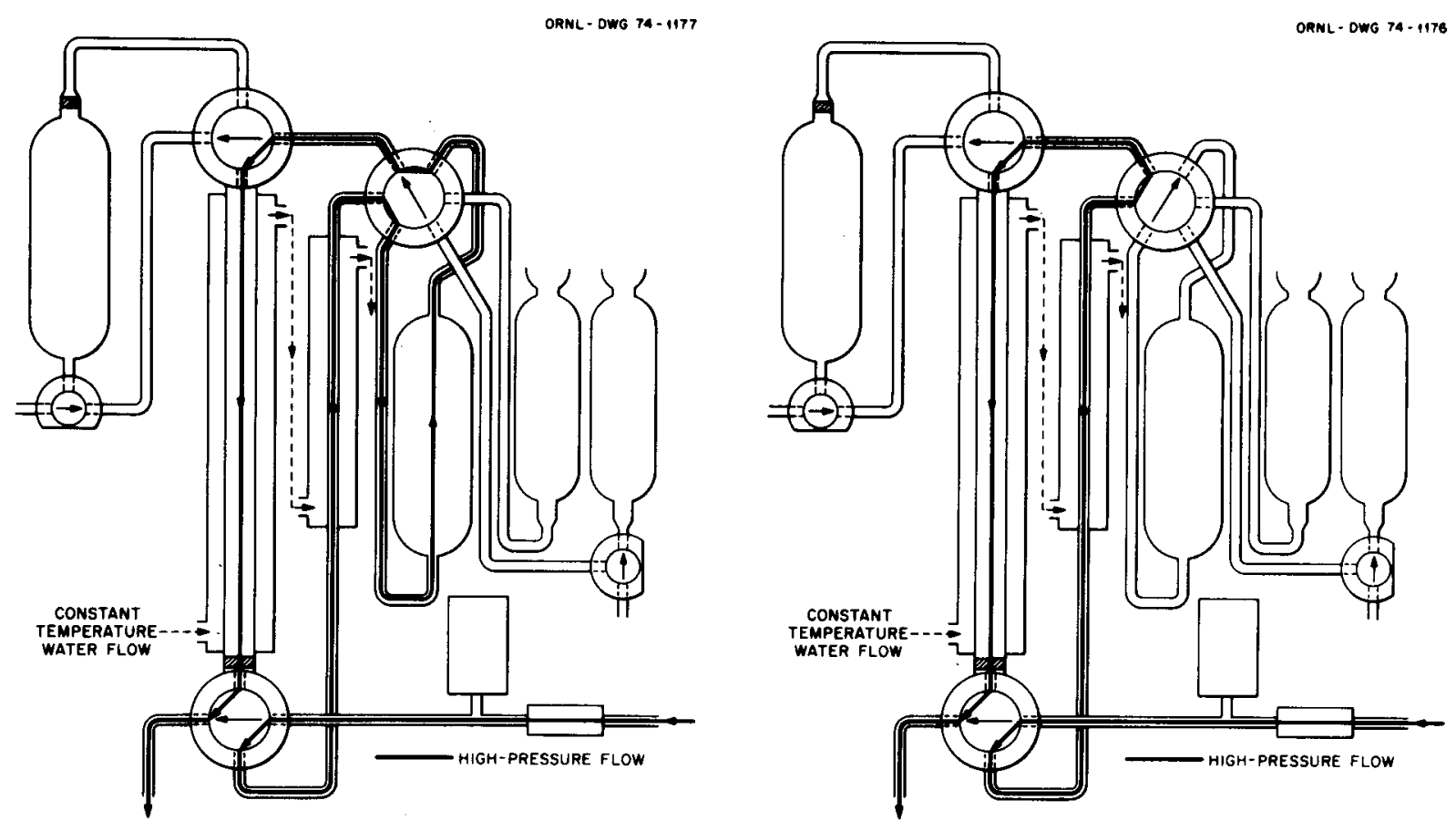

Fig. 3. High-pressure Displacement of Column Charge onto Resin Column.

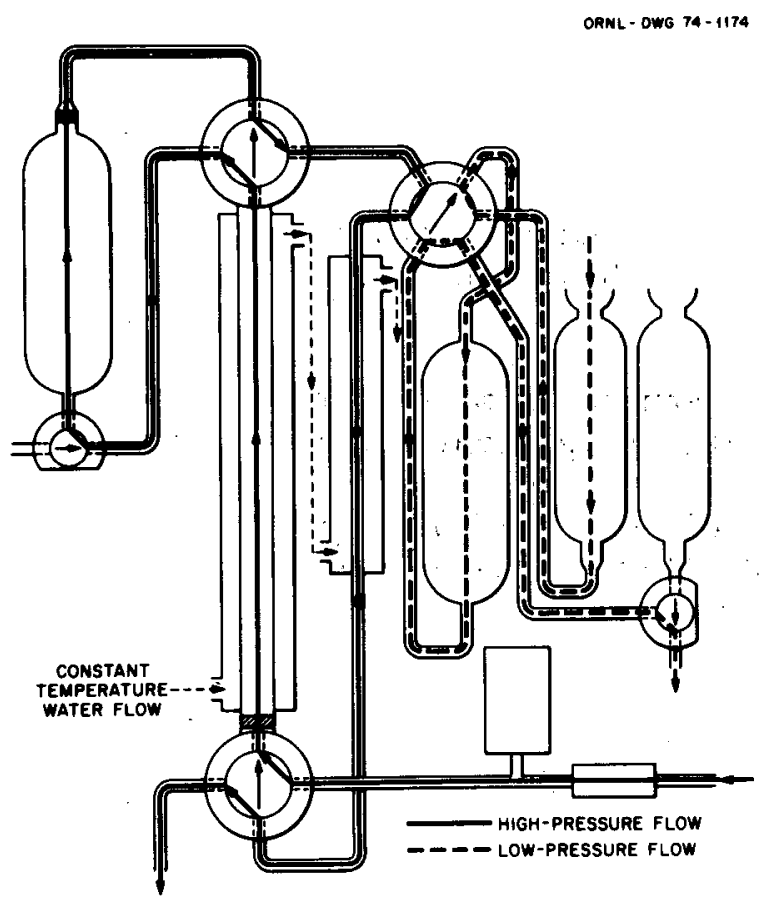

Fig. 4. Resin Column Elution Sequence.

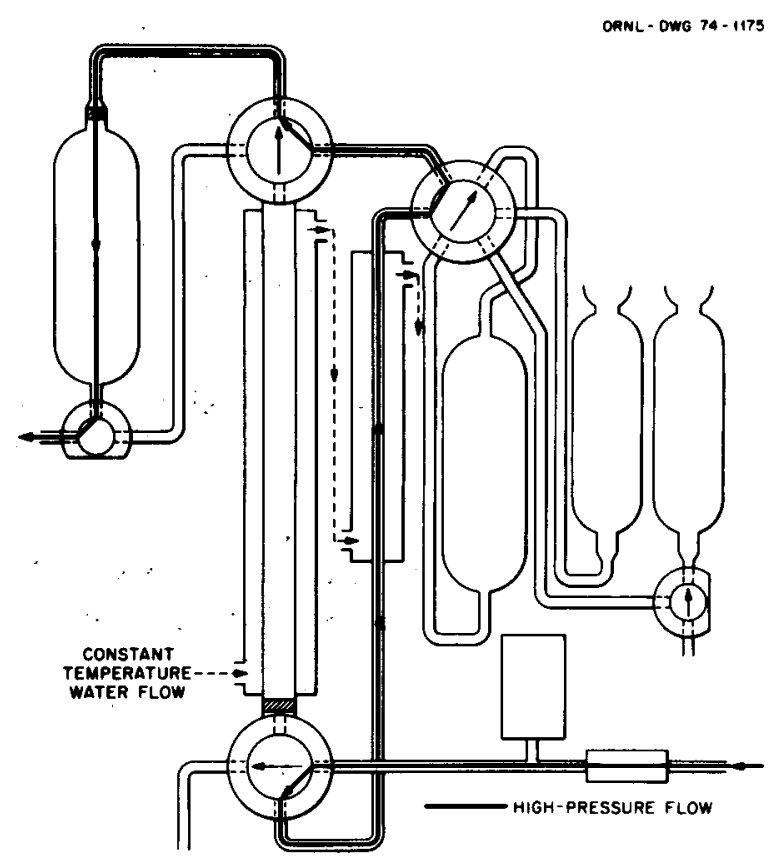

Fig. 5. Resin Backwash from Column and Load-loop Cleaning Flow Patterns.

Fig. 6. Removal of Spent Resin from the Apparatus. 
The equipment was tested before use in the hot cell. A mixture containing 10\% gadolinium and $90 \%$ europium was used as feed. This feed was spiked with radioactive gadolinium and europium tracers by adding a small amount of irradiated europium from a production run.

The procedure that has been described was used during the test runs except as noted. The ionization chamber available at that time lacked sufficient sensitivity when only tracer levels of radiation were present.

Consequently, the effluent stream was not monitored continuously, but 10-mL samples were taken at intervals and analyzed by gamma scan.

Measurements were made of the effectiveness of the transfer of the charge from the feed reservoir to the column. After the transfer of the feed to the column, the liquid in the reservoir was drained into a beaker, and its gadolinium-153 and europium-152 contents were determined analytically.

Direct measurements were made of the distribution coefficients of gadolinium and europium between the resin and various solutions that might be involved in this work. Small samples of resin were weighed and then agitated with the solutions which contained radioactive gadolinium and europium tracers. The resin samples were washed with distilled water and dried, and their gadolinium and europium contents were determined by gamma scan. Aliquots of the solutions were also taken and were analyzed in the same manner.

The elution curves of three of the runs are given in Figs. 7 through 9 . In runs $B$ and $I$ (Figs. 7 and 9 ), the elution was continued until both the gadolinium and europium peaks were developed. In other runs, elution was stopped when the minimum between the peaks was clearly past. The gadolinium peaks were nearly symmetrical in all runs. No gadolinium tailings were observed in these tracer runs but probably occurred at a level below the level of detection of gadolinium-153. The gadolinium concentration was still descending in an essentially linear manner at the lowest observed concentration in all cases. In one case, this concentration was 0.0007 of the peak height.

The europium curves are skewed. This results from the fact that significant fractions of the capacities of both the elutant and resin are used.

Run I (Fig. 9) was carried out at the highest loading level tested, that is, $1.8 \mathrm{~g}$ of dissolved oxides. Run F (Fig. 8) was at one-half of this level, $0.9 \mathrm{~g}$ of dissolved oxides. 


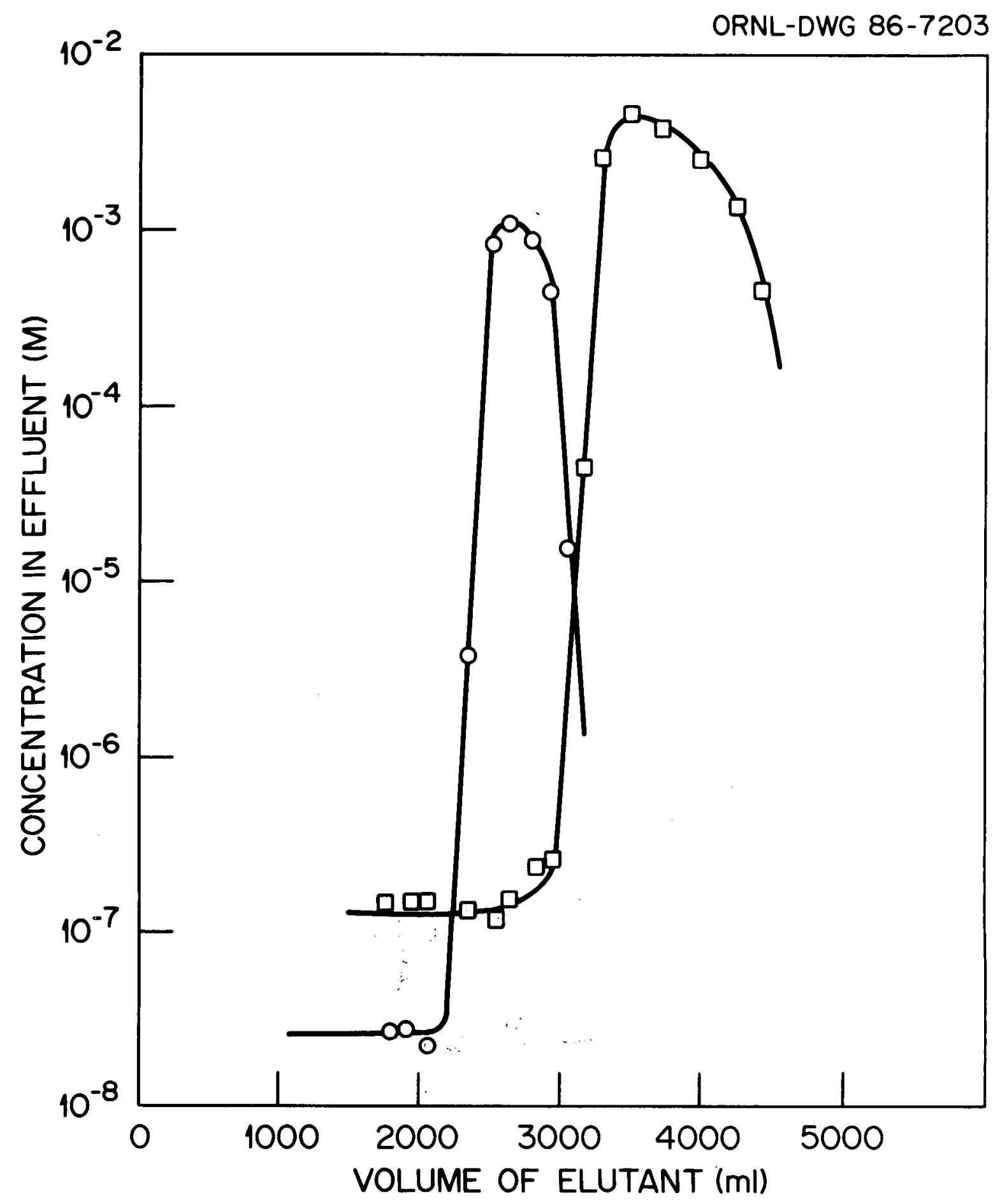

Fig. 7. Run B. The feed was equivalent to $1.5 \mathrm{~g}$ of irradiated $\mathrm{Eu}_{2} \mathrm{O}_{3}$. $\bigcirc$-Gadolinium concentration in effluent; $\square$-europium concentration in eff luent. 


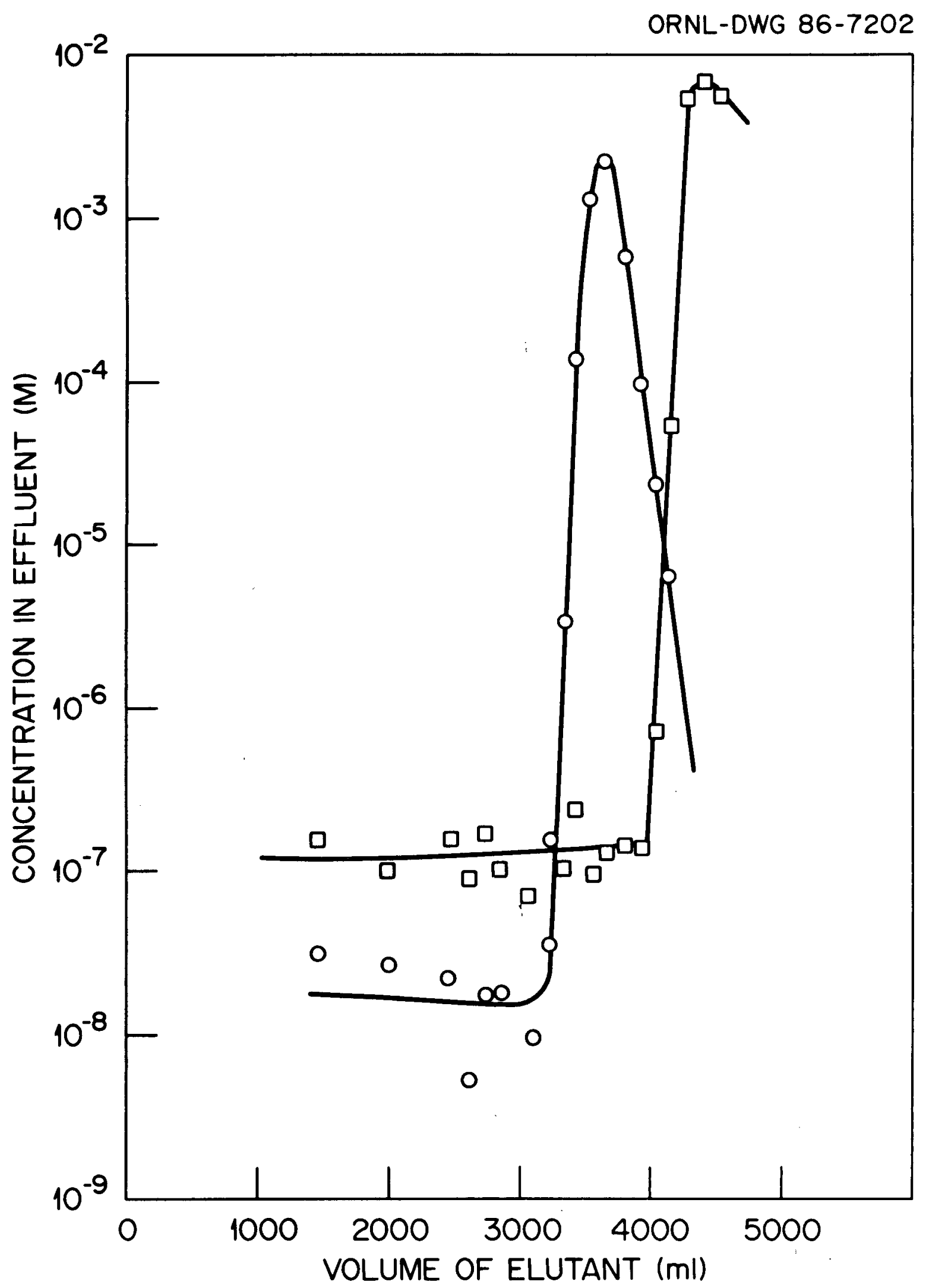

Fig. 8. Run $F$. The feed was equivalent to $0.9 \mathrm{~g}$ of irradiated Eu $\mathrm{O}_{3}$. O-Gadolinium molarity in the effluent; $\square$-europium molarity in the eff luent. 


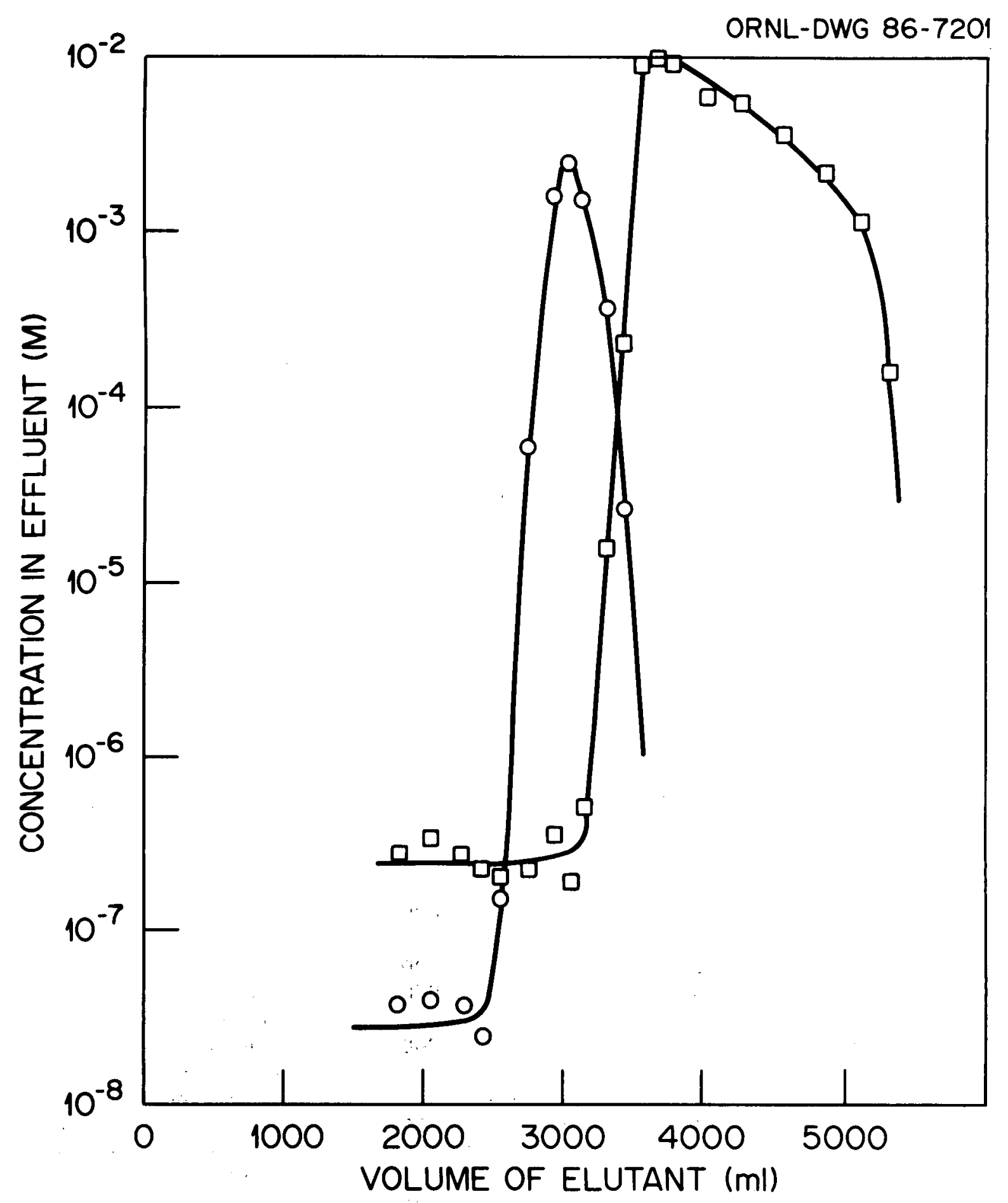

Fig. 9. Run I. The feed was equivalent to $1.8 \mathrm{~g}$ of irradiated $\mathrm{Eu}_{2} \mathrm{O}_{3}$. $\bigcirc$-Gadolinium molarity in the effluent: $\square$-europium molarity in the eff luent. 
Table 2 summarizes the conditions of all of the test runs made. The ratio of the gadolinium peak height to the point of intersection of the gadolinium and europium curves is a measure of the sharpness of separation. Run A was defective. The constant-temperature bath failed, and the charge remained in the column overnight before elution was started. Run $J$ was carried out at a much higher pH than normal. The most obvious correlation is between batch size and sharpness of separation. Better separations were achieved with smaller batches.

Table 2. Test runs of ionization column

\begin{tabular}{|c|c|c|c|c|}
\hline Run & $\begin{array}{l}\text { Loading, } \\
\text { equivalent } \\
g \text { of oxide }\end{array}$ & $\begin{array}{l}\text { Gd peak } \\
\text { height } \div \\
\text { height at } \\
\text { intersection }\end{array}$ & $\begin{array}{c}\text { Width of Gd peak } \\
\text { at } 10 \% \text { of peak } \\
\text { height } \\
(\mathrm{mL})\end{array}$ & Special conditions \\
\hline A & 1.50 & 7.14 & 780 & $\begin{array}{l}\text { 16-h delay between } \\
\text { column charging and } \\
\text { elution. Loaded at } \\
\text { room temperature. }\end{array}$ \\
\hline B & 1.50 & 88.8 & 530 & $\begin{array}{l}\mathrm{LiNO}_{3} \text { was rinsed from } \\
\text { the column with } 300 \mathrm{~mL} \\
\text { of } 0.25 \mathrm{M} \mathrm{NH}_{4} \mathrm{NO}_{3}\end{array}$ \\
\hline $\mathrm{C}$ & 1.20 & 226 & 480 & $\begin{array}{l}\text { LiNO3 was rinsed from } \\
\text { the column with } 60 \mathrm{~mL} \\
\text { of } 0.25 \mathrm{M} \mathrm{NH}_{4} \mathrm{NO}_{3}\end{array}$ \\
\hline D & 1.20 & 32.9 & 660 & $\begin{array}{l}\text { LiNO } 3 \text { was rinsed from } \\
\text { the column with } 100 \mathrm{~mL} \\
\text { of } 0.25 \mathrm{M} \mathrm{NH}_{4} \mathrm{NO}_{3}\end{array}$ \\
\hline $\mathrm{E}$ & 1.60 & 68.1 & 760 & No $\mathrm{NH}_{4} \mathrm{NO}_{3}$ Rinse \\
\hline F & 0.90 & 491 & 460 & $\begin{array}{l}\text { Loaded at room temp- } \\
\text { erature. No } \mathrm{NH}_{4} \mathrm{NO}_{3} \\
\text { rinse }\end{array}$ \\
\hline G & 0.90 & 203 & 660 & $\begin{array}{l}\text { Elutant solution passed } \\
\text { through feed reservoir }\end{array}$ \\
\hline $\mathrm{H}$ & 0.90 & 426 & 400 & No $\mathrm{NH}_{4} \mathrm{NO}_{3}$ rinse \\
\hline I & 1.80 & 65.3 & $\mathbf{5 7 0}$ & $\begin{array}{l}\text { Heaviest loading } \\
\text { tested }\end{array}$ \\
\hline $\mathbf{J}$ & 1.80 & 3.9 & 760 & $\begin{array}{l}\text { Elutant } \mathrm{pH}=5.06 \\
\text { LiNOs pumped into } \\
\text { column before testing }\end{array}$ \\
\hline K & 0.8 & 147 & 470 & $\begin{array}{l}\text { Elutant } \mathrm{pH}=4.4 . \\
\text { Elutant passed through } \\
\text { feed reservoir }\end{array}$ \\
\hline $\mathrm{L}$ & 0.9 & 22.9 & 520 & Elutant $\mathrm{pH}=4.4$ \\
\hline
\end{tabular}

In some cases, the lithium nitrate and acid were rinsed from the column using $0.25 \underline{M}$ ammonium nitrate, but beginning with Run $E$, this was not done. 
This had no apparent effect on the separation. The elimination of the ammonium nitrate does not save time because a larger amount of elutant is needed when it is not used.

Table 3 shows the physical separation of gadolinium from europium if the effluent was divided exactly at the minimum between the peaks. These values were calculated by extrapolating the legs of the two peaks to zero concentration. They do not include europium that was present because of imperfect decontamination of the resin. The curies of europium per curie of gadolinium-153 were calculated neglecting the europium-156. These separations are excellent by most standards but, as will be noted later, cannot be achieved under conditions of heavy radiation damage. The calculated radiochemical purities did not meet product specifications even under these ideal conditions.

Table 3. Separation of gadolinium from europium at minimum between curves

\begin{tabular}{|c|c|c|c|c|}
\hline Run & Loadgeguigalent & (\% of togsa 1 ) & $\begin{array}{l}\text { ( } \% \text { of totad Eu } \\
\text { in column feed) }\end{array}$ & $\begin{array}{l}\text { Curies Eu per curie } \\
\text { Gd- } 153^{*}\end{array}$ \\
\hline
\end{tabular}

\begin{tabular}{lllll}
\hline B & 1.50 & 0.4 & 0.02 & 0.002 \\
C & 1.20 & 0.06 & 0.03 & 0.003 \\
D & 1.20 & 0.2 & 0.03 & 0.004 \\
E & 1.60 & 0.05 & 0.02 & 0.002 \\
F & 0.90 & 0.06 & 0.01 & 0.0006 \\
G & 0.90 & 0.1 & 0.02 & 0.0008 \\
H & 0.90 & 0.06 & 0.01 & 0.0005 \\
I & 1.80 & 0.01 & 0.03 & 0.001 \\
K & 0.80 & 0.1 & 0.03 & 0.001 \\
L & 0.90 & 2.0 & 0.2 & 0.01 \\
\hline
\end{tabular}

*Europium-156 was neglected.

In ion exchange, the product purity can be improved at the expense of product recovery. The point at which the gadolinium in the effluent stream fell below the specified radiochemical purity. (99.99\%) is given in Table 4 . Again, the europium-156 and residual europium due to imperfect decontamination were neglected.

The effectiveness of transfer of feed from the reservoir to the column varied from $93 \%$ to $99.93 \%$. The very high efficiencies occurred when the ammonium nitrate rinse solution or the eluting solution was passed through the reservoir. This, however, increased the amount of solution required and probably caused some reduction in the sharpness of the europium/ gadolinium separation. Efficiencies of $99.8 \%$ were obtained when the flow of lithium nitrate solution was started at a low level, about $4 \mathrm{~cm}^{3} / \mathrm{min}$. After a few minutes, the flow could be doubled. In these tests, flow was diverted to bypass the reservoir after $100 \mathrm{~mL}$ of $10 \%$ lithium nitrate solution was pumped. 
Table 4. Point at which europium exceeds product specifications

\begin{tabular}{lcc}
\hline Run & $\begin{array}{c}\text { Load equivalent } \\
\text { equivalent } \mathrm{g} \text { of oxide }\end{array}$ & $\begin{array}{c}\text { Cut-off point } \\
\text { (fraction of Gd-153 } \\
\text { peak height) }\end{array}$ \\
\hline B & 1.5 & 0.55 \\
C & 1.2 & 0.40 \\
D & 1.2 & 0.43 \\
E & 1.6 & 0.62 \\
F & 0.9 & 0.06 \\
G & 0.9 & 0.18 \\
H & 0.9 & 0.04 \\
I & 1.8 & 0.19 \\
K & 0.8 & 0.04 \\
L & 0.9 & 0.23 \\
\hline
\end{tabular}

The distribution coefficients that were measured directly are given in Table 5. They are defined as the microcuries/gram of resin, air dried at room temperature, divided by the microcuries/milliliters of solution equilibrated with the resin.

Table 5. Distribution coefficients

\begin{tabular}{|c|c|c|}
\hline \multirow{2}{*}{ Solution } & \multicolumn{2}{|c|}{ Distribution coefficienta } \\
\hline & Gadolinium & Europium \\
\hline $10 \% \mathrm{LiNO}_{3}$ and $0.05 \mathrm{M} \mathrm{HNO}_{3}$ & 49 & 46 \\
\hline $0.50 \underline{\mathrm{M}}$ АHIB $(\mathrm{pH}-5.0)^{\mathrm{b}}$ & 2.1 & 2.5 \\
\hline $0.25 \underline{\mathrm{M}} \mathrm{NH}_{4} \mathrm{NO}_{3}$ & 6000 & 4800 \\
\hline $3.00 \underline{\bar{M}} \mathrm{NH}_{4} \mathrm{NO}_{3}$ & 13.7 & 13.4 \\
\hline $3.00 \overline{\mathrm{M}} \mathrm{HNO}_{3}$ & 19 & 19 \\
\hline $0.50 \overline{\mathrm{M}}$ EDTA pH $=5.0^{\mathrm{b}}$ & 0.007 & 0.01 \\
\hline $0.25 \overline{\mathrm{M}}$ EDTA $\mathrm{pH}=5.0^{\mathrm{b}}$ & 0.02 & 0.03 \\
\hline
\end{tabular}

athe distribution coefficient is defined as the microcuries/g of resin, air dried at room temperature, divided by the microcuries/mL in the solution at equilibrium.

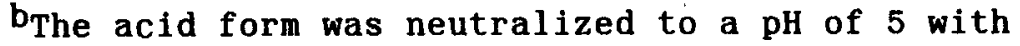
ammonium hydroxide.

If expressed as microcuries/milliliters of resin bed divided by microcuries/milliliters of solution, the values would be lower. Furthermore, these values were determined as tracer-level loadings. At high loading, the values would be depressed. 
The distribution coefficients in the lithium-nitrate solution are low enough that the flow of this solution will cause some movement of the absorbed band in the column to the detriment of separation. The $0.25 \underline{M}$ ammonium nitrate will move the absorbed band very little because of the high distribution coefficients.

The distribution coefficients observed with $3 \mathrm{M}$ ammonium nitrate, $3 \underline{M}$ nitric acid, and $0.5 \mathrm{M}$ AHIB are low enough to make these solutions effective in the decontamination of resin, but large volumes must be used. The nitric acid may have some extra advantage for the decontamination of resin that has suffered radiation damage. The strong acid would suppress the ionization of carboxylic acid radicals that are formed. The ethylenediamine tetraacetic acid (EDTA) shows the most favorable distribution coefficients for decontamination.

Decontamination after the test runs always involved an initial passage of $1 \mathrm{~L}$ of $0.5 \mathrm{M}$ AHIB at a pH of 5.0 through the column. This removed most, but not quite all, of the europium and gadolinium. Secondary decontamination was accomplished in some cases by the passage of $250 \mathrm{~mL}$ or more of $3.0 \mathrm{M}$ nitric acid through the column. In other cases, the column was filled with $0.5 \mathrm{M}$ EDTA solution. This was allowed to stand for a time to thoroughly equilibrate. It was then replaced by a second shot. After equilibration, the EDTA was washed from the column with distilled water. Both the nitric acid and EDTA were effective in decontaminating the resin.

\section{Production Experience}

As of this writing, two high-pressure ion-exchange columns are being operated in a hot cell. Although production has been increased substantially, radiation damage has caused problems. It has been necessary to change resin every six to eight runs. This damage is documented by the elution curves produced by the recorder connected to the lonization chamber that monitors the gross radiation coming from the effluent from the column. The first elution curve obtained with new resin looks much like the elution curves shown in this report. There is a sharp gadolinium peak followed by a deep valley and then a quickly ascending europium peak. With successive runs, the valley becomes shallow until only a gradually descending slope follows the gadolinium peak. The signal falls only a little below the peak value before the rapidly ascending europium peak starts. This indicates serious gadolinium tailing and consequently appreciable gadolinium losses.

Future development will be directed toward the reduction of radiation damage. Three approaches will be used.

1. More work is being done on the partial removal of the europium before the ion-exchange step.

2. Methods of shortening the exposure time of the resin will be sought. 
3. The effect of eliminating oxidizing agents during the time of heavy radiation exposure will be sought.

Lower-cost ion-exchange resins will be tested in tracer-level runs. The use of one of these resins would lower operating costs and/or allow more frequent resin changes. 


\section{REFERENCES}

1. L. C. Brown and A. P. Callahan, High-Pressure Ion Exchange Column Design for Remote Hot Cell Operation, ORNL/TM-4583, May 1974.

2. D. 0. Campbe11, "Rapid Rare Earth Separation by Pressurized Ion Exchange Chromatography," J. Inorg. Nucl. Chem., Vol 35, pp. 3911-3919 (1973).

3. D. E. Benker, F. R. Chattin, E. D. Collins, J. B. Knauer, P. B. Orr, R. G. Ross, and J. T. Wiggins, "Chromatographic Cation Exchange Separation of Decigram Quantities of Californium and Other Transplutonium Elements," ACS Symposium Series No. 161, Transplutonium Elements - Production and Recovery, James D. Davratil and Wallace $W$. Schuttz, Ed., American Chemical Society

4. David 0. Campbell, Rapid Ion Exchange Separations, I\&EC Process Design and Development, Vol 9, p. 95 (January 1970).

5. H. Louise Smith and Darlene C. Hoffman, Ion-Exchange Separations of the Lanthanides and Actinides by Elution with Ammonium Alpha-HydroxyIsobutrate, J. Inorg. Nucl. Chem., Vol 3, p. 244 (1956). 
更

更 
ORNL/TM -9988

Distribution Category UC-70

INTERNAL DISTRIBUTION

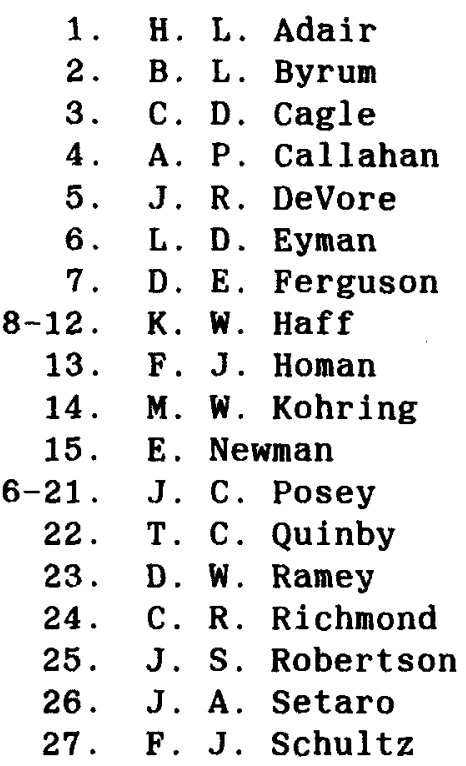

28. C. D. $S \cot t$

29. W. D. Simpson

30. S. H. Stow

31. G. W. Strandberg

32. J. H. Swanks

33. W. G. Tatum

34. J. A. Tompkins

35. D. B. Trauger

36. D. R. Watkins

37. J. S. Wike

38. R. S. Wiltshire

39. S. J. Wolfe

40. Central Research Library

41. Document Reference Section

42-43. Laboratory Records

44. Laboratory Records - RC

45. ORNL Patent of fice

\section{EXTERNAL DISTRIBUTION}

46. J. J. Jicha, Jr., Director, Research and Development and Byproducts Division, Office of Defense Waste and Byproducts Management, Mail Stop B-107, U.S. Department of Energy, Washington, D.C. 20545.

47-51. J. A. Lenhard, Assistant Manager for Energy Research and Development, Oak Ridge Operations office, U.S. Department of Energy, Post office Box E, Oak Ridge, TN 37830 .

52. J. N. Maddox, Office of Defense Waste and Byproducts Management, ER-73, U.S. Department of Energy, Washington, D.C. 20545.

53. W. C. Remini, Program Manager, Byproducts Utilization, Research and Development and Byproducts Division, office of Defense Waste and Byproducts Management, Mail Stop B-107, U.S. Department of Energy, Washington, D.C. 20545.

54-378. Given distribution as shown in TID-4500 under UC-70 - Nuclear Waste Management. 